\title{
Climate Change and the Absence of an International Investment Organization
}

Hilmar Pór HILMARSSON ${ }^{1}$

\begin{abstract}
The global needs for investment in clean energy are vast and can only be met if resources are pooled from different sources; public, private, and donor funds. This is especially true for capital intensive projects such as geothermal and hydropower. While government funds are important, many developing and emerging countries do not have the tax base to fund large, capital intensive, long term projects. International Financial Institutions such as the World Bank and the regional development banks could help capital mobilization for clean energy projects and facilitate cooperation with the private sector. One important obstacle in scaling up clean energy projects today is that no comprehensive multilateral agreement on foreign investments exists. Additionally, no multilateral institution is engaged in cross border investments in the same way as for cross border trade. No World Trade Organization exists for investment. This can be an obstacle for global efforts to promote cross border climate friendly investment and an impediment for private sector flows.
\end{abstract}

Keywords: Clean energy investments, climate change, international financial institutions (IFIs)

JEL classification: F30, G22, P18, Q40

DOI: $10.24818 /$ RMCI.2018.3.274

\section{Introduction}

Climate change is perhaps among the most serious challenges humankind has ever faced. This is a global problem that has the potential to become a fundamental threat to economic development and human well-being on the earth, so that urgent action is needed.

Natural scientists are not the only ones expressing concern about climate change. Economists, financial analysts and political scientists, among others, are now also increasingly engaged in this field. The problem is no longer only one for geoscientists and engineers. Climate change can have serious economic, financial and political consequences. Sir Nicholas Stern, a former chief economist at the World Bank Group, led a panel to review the evidence for climate change and to assess its economic implications. The Stern Commission's key message was that: "An overwhelming body of scientific evidence now clearly indicates that climate change is a serious and urgent issue. The Earth's climate is rapidly changing, mainly as a result of increases in greenhouse gases caused by human activities." (Stern Commission, 2006, p. 2). The Intergovernmental Panel on Climate Change states

${ }^{1}$ Hilmar Pór HILMARSSON, Ph.D., Professor, University of Akureyri, School of Business and Science, Iceland, E-mail: hilmar@unak.is 
that "The human influence on the climate system is clear and is evident from the increasing greenhouse gas concentrations in the atmosphere, positive radiative forcing, observed warming, and understanding of the climate system." ${ }^{2}$ In his book Earth-A Tenant's Manual, Rhodes states that "These increases in greenhouse gases are the clear result of human activity, reflecting the growing emissions produced by increased industrialization, transport, deforestation, intensive agriculture, urbanization, and growing population. And the gases have long atmospheric lifetimes...." (Rhodes, 2012, p. 172). Political scientists are also turning their attention to the problem. Robert Keohane, who has published extensively on the global politics of climate change, states that scientific consensus on the seriousness of the climate threat has increased (Keohane, 2015, p. 20). Finally, the World Bank recently stated that "science is unequivocal that humans are the cause of global warming, and that major changes are already being observed" (World Bank, 2015, p. 18).

Although the consensus on the seriousness of the climate threat has increased in recent years, some debate still remains about the influence of human activity on climate change. Rhodes, for example, states that: "Because records of high greenhouse gas concentrations show [a] strong correlation with higher temperatures in ice cores, these increases are assumed to compound natural temperature increases. There is no significant disagreement in the scientific community on this point. The debate, rather, is about the degree of impact and future scale and timing of human influence on global warming" (Rhodes, 2012, p. 172). A small number of skeptics can still be found among natural scientists about the causes of climate change but this article will not discuss the matter in any detail.

The consequences of climate change can become dramatic. In his book, The Climate Casino - Risk, Uncertainty, and Economics for a Warming World, Nordhaus, for example, states that these include sea-level rise, more intense hurricanes, losses of species and ecosystems, acidification of the ocean, as well as threats to the natural and cultural heritage of the planet (Nordhaus, 2013). Currently the most striking evidence of climate change perhaps comes from the shrinking coverage of polar ice as can be seen in Greenland and Iceland, for example.

When discussing the effective response to climate change, the Stern Review states that: "Climate change is the greatest market failure the world has ever seen, and it interacts with other market imperfections. Three elements of policy are required for an effective global response. The first is the pricing of carbon, implemented through tax, trading or regulation. The second is policy to support innovation and the deployment of low-carbon technologies. And the third is action to remove barriers to energy efficiency, and to inform, educate and persuade individuals about what they can do to respond to climate change" (Stern Review, 2006, p. viii). While all those issues are important, this article will mainly focus on the deployment of low carbon technologies via the utilization of underutilized

\footnotetext{
${ }^{2}$ See Intergovernmental Panel on Climate Change, Fifth Assessment Report, see https://www.ipcc.ch/report/ar5/index.shtml
} 
renewable energy sources. Clean energy investments such as geothermal and hydropower.

\section{Economic Theory and Negative Externality}

In economic theory pollution is considered a negative externality. ${ }^{3}$ It is a byproduct of human activity and pollutants cause damage to innocent bystanders. Emission of carbon dioxide and other greenhouse gases is causing damage now and will do so in the future. These gases negatively impact global climate change. As Nordhaus put it "The problem is that those who produce the emissions do not pay for that privilege, and those who are harmed are not compensated" (Nordhaus, 2013, p. 17) and "governments must step in and regulate or tax activities with significant harmful externalities." (Nordhaus, 2013, p. 19)

One can distinguish between local and global externalities. Emission of carbon dioxide can for example adversely impact the health of people in the country they live in and can thus be called negative local externality. But carbon dioxide emissions not only affect local communities. They also have a negative impact on the entire global community that stands to lose from increased carbon dioxide emissions. This is because carbon dioxide emissions from one country affect all countries through their impact on global climate. Human activity thus imposes long lasting costs on bystanders without compensation. This is the essence of the market failure.

Any solution to the problem of climate change must be a global solution. Piecemeal solutions will not do. The participation and leadership of all major powers, most notably the United States, the European Union (EU), China, and India is required. As Frank Rhodes states: "The United States... has about 5 percent of the world's population but produces about a quarter of all [greenhouse gas emissions]. Though China now slightly exceeds the U.S. total emission, it has a population of four times that of the United States, and its level of [greenhouse gas emissions] is growing rapidly" (Rhodes, 2012, p. 181). The battle against climate change thus requires cooperation and coordination among developing, emerging and high income countries.

This article focuses on investment in clean renewable energy sources that are capital intensive. This is because investment in renewable energy sources can help shift the world away from high-carbon fossil fuels. Its focus is on investment in developing and emerging markets, currently the fastest growing economies in the world in terms of Gross Domestic Product growth, energy use and emissions. Most of the future increase in energy demand will be in developing and emerging markets. This is also where most clean energy sources are located.

It is widely believed that global warming will have more serious consequences in developing countries than in high income developed countries. We

\footnotetext{
${ }^{3}$ Externality can be defined as a consequence of an industrial or commercial activity which affects other parties without this being reflected in market prices, see for example: http://www.oxforddictionaries.com/definition/english/externality
} 
know that developing countries currently possess vast underutilized clean energy resources. Why are these resources not used on a larger scale and what needs to be done to take advantage of those resources to help remedy the problems of climate change for those countries and, indeed, for the whole world?

Many challenges are related to increased use of renewable sources such as geothermal and hydropower. As the World Bank has stated: "Capital intensive infrastructure projects have a number of distinctive features: (i) they require significant upfront capital and take many years to payback; (ii) output is typically sold on a basis of long term contracts; (iii) and permitting risks can be significant" (World Bank, 2012, p. 3). And furthermore: "low-emission projects tend to have higher upfront costs; produce less output per unit of capacity; and have higher perceived risks than conventional infrastructure projects."

The geothermal sector is currently a market niche that has a substantial global market opportunity with significant growth rates in coming years. In fact, according to the International Financial Corporation: "Around 40 countries worldwide, including several low and middle income countries, have the potential to meet a sizeable proportion of their electricity demand through geothermal power, at a relatively low cost (around \$.08 per kilowatt hour)" (International Financial Corporation, 2014, p. 52). One can say that geothermal is like an infant that has not been taken care of. The need is to step up local and global efforts. This article is also relevant for large hydropower projects built in a challenging business and investment environment to show how the international community can help make such investments available with the appropriate lending and risk mitigation instruments. This requires the cooperation, coordination and commitment of many different players, including host governments, the international community via international financial institutions, bilateral agencies and donors as well as the private sector. The World Bank recently stated that it "is working to leverage both public and private sources of climate finance to support climate-smart policy and investments and help countries and business adapt to a changing climate" (World Bank, 2015, p. 18).

The global warming externality can be eliminated by setting an appropriate price for carbon. But further action is needed. Indeed, simultaneous multiple action is required, including: (i) the pricing of carbon (implemented through tax, trading or regulation), (ii) policy to support innovation and the deployment of low-carbon technologies, and (iii) action to remove barriers to energy efficiency, and to inform, educate and persuade individuals about what they can do to respond to climate change.

This includes clean energy investments. As Nordhaus has argued, “...if other policies fail, development of low-carbon technologies is the last refuge for achieving our climate goals" (Nordhaus, 2013, p. 289). 


\section{Fossil Fuels Still Dominate in Global Primary Energy Consumption}

Renewables account for only a small share of global primary energy consumption, which is still dominated by fossil fuels: about 30 percent each for coal and oil and 25 percent for natural gas (see Table 1). Progress in the development of renewables could be fragile if fossil fuel prices are low for long. Low prices for oil, gas and coal can slow down innovation and adoption of cleaner technology. Policymakers should not allow this to happen.

Table 1. Share of Primary Energy Consumption in 2014 (percentage points)

\begin{tabular}{|l|l|l|l|l|l|}
\hline & Oil* & Natural Gas** & coal ${ }^{* *}$ & Nuclear Energy & Renewables \\
\hline World & 3 & 24 & 3 & 4 & 9 \\
& 3 & & 0 & & \\
\hline Unite States & 3 & 30 & 2 & 8 & 5 \\
& 6 & & 0 & & 1 \\
\hline China & 1 & 6 & 6 & 1 & 0 \\
\hline $\begin{array}{l}\text { European } \\
\text { Union }\end{array}$ & 3 & 22 & 1 & 12 & 1 \\
\hline
\end{tabular}

*Oil is mostly to power transportation.

**Coal and natural gas are mainly used for electricity generation.

Source: Arezki and Obstfeld, $2015^{4}$

In 2016 nations from around the world gathered in Paris for the United Nations Climate Change Conference, with the goal of a universal agreement on reducing greenhouse gas emissions. The Paris climate summit ${ }^{5}$ adopted a new agreement. It does not ensure or spell out the end of fossil fuels or assure that temperatures will not rise more than two degrees. Nevertheless, the Paris Agreement has the potential to mark a historic shift in how the world negotiates cooperation on climate change. Only time will tell if the full promise of the Paris Agreement will ever be achieved. The exit of the USA and uncertain re-entry greatly weakens the agreement ${ }^{6}$ and its re-entry remains uncertain.

Utilizing additional funds for clean energy investment is not only a national effort but also an international effort. It is a test for developing and emerging market countries but also for international financial institutions (IFIs) to assist those countries make the transition. So far IFIs, including the World Bank and the regional

\footnotetext{
${ }^{4}$ The Price of Oil and the Price of Carbon, see http://blogimfdirect.imf.org/2015/12/02/the-price-of-oil-and-the-price-of-carbon/

5 Also known as COP 21.

${ }^{6}$ See https://www.theguardian.com/environment/2017/jun/01/donald-trump-confirms-uswill-quit-paris-climate-deal
} 
development banks have been slow to respond (See for example Hilmarsson 2012 and 2017). Those institutions can for example offer loans, guarantees and provide equity to support clean energy projects but they do not provide a comprehensive solution for the problem.

\section{The Lack of an International Investment Organization}

The absence of a global government makes global warming an awesomely challenging problem to manage. Very broad participation is needed to fully address the global "tragedy of the commons" that results when countries fail to take into account the negative impact of their carbon emissions on the rest of the world. Furthermore, free riding by non-participants, if sufficiently widespread, can undermine the political will to action of participating countries (Arezki and Obstfeld, 2015).

The lack of a comprehensive foreign investment regime also makes risk management for cross border clean energy investments more difficult. No comparable international organization exists to deal with cross border investments in the same way as the World Trade Organization does for trade. The lack of an international framework for cross-border investment makes political risk mitigation challenging. Cross border investment is less likely to take place unless proper risk mitigation is possible, feasible and fair for all parties involved.

Robert O. Keohane and David G. Victor (2011) have examined the international climate regime. They argue that " $[\mathrm{t}] \mathrm{he}$ international institutions that regulate issues related to climate change are diverse in membership and content. They have been crafted at different times, and by different groups of countries. They have been crafted in a context of diverse interests, high uncertainty, and shifting linkages. They are not integrated, comprehensive, or arranged in a clear hierarchy. They form a loosely-linked regime complex rather than a single international regime" (Keohane and Victor, 2011, p. 20). Keohane and Victor argue that "The infeasibility of a strong comprehensive regime makes climate change a very difficult international problem to manage" (Keohane and Victor, 2011, p. 20). Furthermore "The failure of efforts to develop a comprehensive, integrated climate regime reflects resistance to costly policies in rich countries, such as the United States, and in developing countries alike" (Keohane and Victor, 2011, p. 8). They conclude that "At the present juncture, however, both political reality and the need for flexibility and diversity suggest that it is preferable to work for a loosely linked but effective regime complex for climate change" (Keohane and Victor, 2011, p. 20). However, it is not clear how a loosely linked regime would operate and how it would differ from the current system that has not yet produced favorable results.

Currently about 3000 bilateral investment treaties are in force. As Salacuse (2010) states, this emerging regime for international investment significantly differs from other international regimes. Three of the most important are that: (1) the regime has largely been constructed bilaterally, rather than multilaterally; (2) it gives broad scope to private and decentralized decision making; and (3) no multilateral 
international organization supports the investment regime (Salacuse 2010, p. 463). In fact, if one considers Keohane's definition of cooperation as the "co-ordinated mutual adjustment of states policies yielding benefits to participants"7 one can also argue that institutionalized cooperation in the field of foreign investment does not exist.

The current investment regime has been founded on the assumption that it will increase international investment, which will then lead to increased prosperity and economic development (Salacuse 2010, p. 468). However, it has been questioned whether investment treaties have in fact increased investment flows to poor countries.

The World Bank, for example, has stated that "[e]ven the relatively strong protections in [bilateral investment treaties] do not seem to have increased flows of investment to signatory developing countries" (World Bank, 2003, p. xvii). Given the fragmented investment regime, it is difficult to identify the specific hegemon that has advanced and maintained the investment treaty system. As Salacuse (2010) has argued "...capital-exporting countries have acted as a collective hegemon to create and maintain the investment regime and thereby maintain their global economic advantage, particularly in relation to developing, capital-importing nations" (Salacuse, 2010, p. 434). Indeed, capital-exporting countries have been the primary force driving negotiation of bilateral investment treaties on which the current investment regime is based. Part of the reason is that after World War II capitalexporting countries felt the need to protect the investments of their nationals. The need for such protection was heightened during the decolonization of territories that had previously been under the control of capital-exporting states.

Why have the nations of the world been willing to negotiate bilateral investment treaties in such large numbers over the last fifty years instead of negotiating global agreements? From a technical perspective it is of course less complicated to negotiate a bilateral agreement than a global treaty that must accommodate the interests of many countries. From a political perspective, given the asymmetric nature of bilateral negotiations between a strong developed country and a usually much weaker developing country, the bilateral setting allows the developed country to use its power more effectively than does a multilateral setting. For example, in multilateral negotiations, developing countries have the opportunity to cooperate with like-minded states to increase their power in negotiations. This would be impossible in bilateral negotiations (Salacuse, 2010, p. 464).

When discussing international investors' efforts to manage political risks, Wells (2005) considers four options: (i) international arbitration, (ii) official political risk insurance, (iii) home government support, and (iv) finally, official credit.

In the absence of a global investment agreement such as the General Agreement on Tariffs and Trade and later the World Trade Organization, investors have turned to piecemeal solutions when protecting their rights in risky countries.

\footnotetext{
${ }^{7}$ Robert Keohane, The Analysis of International Regimes, in Regime Theory, supra note 21 , at 23 .
} 
According to Wells, "[t]hese agreements set out rules for trade, but they provided few rules for investment.....They did nothing to manage the political risks that could hinder foreign investment. Starting with the aborted International Trade Organization of the immediate post-World War II era, several efforts to create a similar global framework for investment came to naught. The history of failure did not encourage renewed efforts to create a comprehensive approach" (Wells, 2005, pp. 89-90). Furthermore, Wells states that " $[t]$ he resulting system, however, was not the product of any grand design but the result of uncoordinated steps by various parties. Certainly, some of the problems of the new system derive from the lack of a single framework; even more important problems can be attributed to the lack of explicit negotiation and mutual acceptance among the affected parties" (Wells, 2005, pp. 89-90).

This failure described by Wells is especially serious if one considers clean energy projects that tend to be large, capital intensive and long term. An additional challenge is that energy resources are to a large extent located in developing and emerging countries that are also currently growing faster than high income industrialized countries, both in terms of Gross Domestic Product and population, and thus also energy use. When host governments in developing and emerging countries cannot make credible long term commitments to foreign investors, those investors will tend to avoid these projects. This becomes especially troubling during times when a global need exists for transition to clean energy projects. As Wells points out, "[t]he need to satisfy the demand for security grew as the international community became increasingly eager to encourage private foreign investors to build infrastructure - roads, power plants, water systems - in the developing world" (Wells, 2005, p. 89). "Without external protection, direct investors in these industries would have to be very brave, or perhaps ignorant, to enter these industries, where they would have little bargaining power once their capital was committed" (Wells, 2005, p. 89).

As mentioned above, Wells (2005) noted four options when discussing international investors' efforts to manage political risks: (i) international arbitration, (ii) official political risk insurance, (iii) home government support, and (iv) official credit.

From the point of view of project investors, option (i), international arbitration, faces the objection that engaging in cross border investment and relying on favorable international arbitration in the event of dispute is not a predictable means of mitigating political risks for foreign investors, but it allows them to escape domestic courts. This can be a lengthy and costly process both for the host country and the foreign investor. The World Bank Group-sponsored International Centre for Settlement of Investment Disputes (ICSID) ${ }^{8}$ is for example a leading international

\footnotetext{
${ }^{8}$ The International Centre for Settlement of Investment Disputes (ICSID) is an autonomous international institution established under the Convention on the Settlement of Investment Disputes between states and nationals of other states. It currently has more than 140 member states. The convention sets forth ICSID's mandate, organization and core
} 
arbitration institution devoted to international investment dispute settlements. ICSID only facilitates resolution of investor-state disputes. In the case of energy projects, the Energy Charter Treaty organization and secretariat whose concern is trade and investment in the energy sector also provides for an investment dispute settlement mechanism. ${ }^{9}$ The Energy Charter Treaty applies to all types of energy, including geothermal energy projects. However, the Energy Charter Treaty can only be used in relation to investors of states and host states that have ratified/acceded to it and it does not enjoy global membership. Arbitration can also be based on bilateral investment agreements that include an arbitration clause.

Option (iii), home government support, may be viable for investors from large countries such as the USA or e.g. larger EU member states but faces the objection that home government support does not sound as promising for investors from less powerful countries such as Iceland. In fact, being an investor from a small country only adds to the risks as small countries can only be expected to wield limited leverage in the event of a dispute with a host government in a The Energy Charter Treaty developing country that could be a much larger country. Options (ii) i.e. official political risk insurance and (iv) i.e. official credit could be a possibility for investors from smaller as well as larger countries to consider when making a foreign investment decision, if feasible venues for cooperation with, e.g., IFIs and export credit agencies ${ }^{10}$ can be found.

If official political risk insurance is chosen from a multilateral institution such as the World Bank's Multilateral Investment Guarantee Agency (MIGA) ${ }^{11}$ or

functions. The intended purpose of ICSID is to provide facilities for conciliation and arbitration of investment disputes. ICSID is one of five institutions that make up the World Bank Group (World Bank, 2015).

${ }^{9}$ The Energy Charter Treaty contains a comprehensive system for settling disputes on matters covered by the Treaty. The two basic forms of binding dispute settlement are state-state arbitration on the interpretation or application of almost all aspects of the Treaty (except for competition and environmental issues), and investor-state arbitration for investment disputes. See http://www.energycharter.org/what-we-do/dispute-settlement/overview/

${ }^{10}$ For discussion about export credit agencies see Dinh and Hilmarsson 2012a, 2012b and 2012c.

11 The Multilateral Investment Guarantee Agency (MIGA) is one of the five organizations included in the World Bank Group. Established in 1988, its intended mission is to promote foreign direct investment into developing and emerging market countries by providing risk insurance/guarantees and credit enhancement and thereby to help support economic growth, reduce poverty, and improve people's lives. MIGA's operational strategy in intended to attract investors and private insurers into difficult operating environments. MIGA is intended to focus on insuring investments in the areas where it can make the greatest difference: (i) countries eligible for assistance from the International Development Association, (ii) fragile and conflict-affected environments, (iii) complex projects that can be transformational, especially in infrastructure and extractive industries, and (iv) middleincome countries where the agency can have an impact. MIGA offers coverage for five non-commercial/political risks. Coverage can be purchased individually or in combination: (i) currency inconvertibility and transfer restrictions, (ii) expropriation, (iii) war, terrorism 
from a bilateral insurer such as the USA's Overseas Private Investment Corporation, ${ }^{12}$ it is important that the insurance policy truly helps the private sector mitigate against risks as this can facilitate capital flows to places where funding is needed. But in addition to the interest of the insured one also needs to consider the interests of the host country and the behavior of the insurer.

From the point of view of the host country as well as the insurer, some issues exist to be concerned about, including two types of moral hazard. First, in the event of a dispute, an insured investor has less incentive to renegotiate a contract than an investor without insurance. The investor may be tempted to walk away from a project without considering adjustment to the terms of the contract in the host country and simply claim the insurance. This can be a serious problem for a host country that is for example faced with a financial crisis such as the regional crisis in Asia in 1997/98 or the global crisis in 2008/09.

Second, the insurer may have an incentive to pay a claim to a foreign investor since its next move can be to make a claim on the host country and collect its money. The World Bank as insurer is often in a strong position vis-à-vis the host country since it may be supporting other projects and programs that will be affected if the host country does not reimburse the bank that just paid out a claim.

But where is the international investment regime heading? One can argue that the world is gradually moving towards an international arrangement on cross border investments. This started with bilateral investment treaties (currently about 3000), then with regional arrangements such as the EU and the North American Free Trade Agreement that have provisions for cross border investments. The next step in this evolution is an inter-regional agreement such as the Trans-Pacific Partnership (TPP) $)^{13}$ and the Transatlantic Trade and Investment Partnership (TTIP). ${ }^{14}$ TPP did not take effect because of exit of the USA from the agreement and was replaced by the Comprehensive and Progressive Agreement for Trans-Pacific Partnership without US participation. ${ }^{15}$ The USA did not terminate the TTIP. ${ }^{16}$

It is possible to view the move from bilateral to regional agreements and then inter-regional agreements as a way to proceed toward a global investment regime

and civil disturbance, (iv) breach of contract and (v) nonhonoring of financial obligations (World Bank, 2015).

${ }^{12}$ For Political Risk Insurance offered by the Overseas Private Investment Corporation, see https://www.opic.gov/what-we-offer/political-risk-insurance

13 Trans-Pacific Partnership, see https://ustr.gov/tpp/ https://www.mfat.govt.nz/en/trade/free-trade-agreements/free-trade-agreementsconcluded-but-not-in-force/trans-pacific-partnership-agreement-tpp/

14 Transatlantic Trade and Investment Partnership, see http://ec.europa.eu/trade/policy/infocus/ttip/

15 Comprehensive and Progressive Agreement for Trans-Pacific partnership. See for example https://www.tpp.mfat.govt.nz/

${ }^{16}$ See https://www.bloomberg.com/news/articles/ 2018-03-29/trump-willing-to-reopen-ttip-amid-eu-u-s-trade-spat-ross-says https://www.cnbc.com/2017/05/30/exclusive-wilbur-ross-says-hes-open-to-resumingttip-negotiations.html 
like the General Agreement on Tariffs and Trade and then the World Trade Organization on trade. However, one could also view this as four stage evolution: (i) bilateral, (ii) regional, (iii) inter regional, (iv) global as taking the attention away from global efforts. The different language used in different agreements can make consolidation of those agreements into a global arrangement difficult.

What could the reasons be for lack of progress towards a global arrangement? One reason could be that it is easier to negotiate with a smaller number of countries participating in regional agreements such as the North American Free Trade Agreement, the Trans-Pacific Partnership and the Transatlantic Trade and Investment Partnership than in a global setting. Geo-political tensions can play a role.

Multilateral investment agreements can be beneficial to developing countries for several reasons including greater availability of the appeals process (e.g. if one compares some bilateral investment treaties with proposals for the Transatlantic Trade and Investment Partnership) as well as consistency of language. Developing countries could also secure a better deal in a multilateral arrangement that involves more than one rich country. This is because rich capital exporting countries will be protecting themselves against cases involving other rich capital exporting countries. This could imply better agreements for developing countries than a bilateral agreement between a rich and a poor country. In other words, rich countries are not as likely to dominate in regional negotiations that include several rich countries or in a global setting where many rich countries are participating.

In addition to the current trend for more multilateral arrangements (regional and inter-regional) another possibility is that bilateral agreements will improve. Cases of countries such as Indonesia withdrawing from the bilateral investment treaty system suggest that as a consequence we might achieve better agreements where multilateral arrangements such as the Transatlantic Trade and Investment Partnership might serve as a model for better bilateral investment treaties.

\section{Challenging Business and Investment Environment}

Utilizing clean energy sources in is a global issue affecting both rich and poor countries. Many developing countries and emerging market countries in Africa, Asia and Latin America possess large geothermal energy resources, but most are only in the early stages of development in making use of those resources. Future growth in demand for electricity is also likely to be strongest in these high-growth emerging regions. A transition to clean energy could be of great benefit to those regions as well as having global implications environmentally, and in the battle against climate change. However, it is not sufficient to have the natural resources and potential growth in future demand. Funding is also needed and energy investments tend to be large, capital intensive and with long repayment periods. In addition to government and donor contributions, private sector participation is also important, resulting in public private partnerships. 
But this does not mean that private sector funds flow to developing countries, which often have challenging business and investment environments that discourage private sector cross border investment, especially those with long repayment periods, as is the case with geothermal and hydro-power projects. For assessment of business environment in different countries see for example the World Bank Doing Business report (World Bank, 2017).

Investors, especially those considering long term investments, will avoid difficult business and investment environments unless risks can be managed. Proper risk mitigation for operators and investors is thus a major challenge in most African countries as well in many developing and emerging countries in Asia and Latin America.

A more thorough review would be needed for a company to make a decision about cross border engagement. Nevertheless, the "Doing Business" report is a useful start to begin identifying challenges in each country. Gaining a fuller understanding of the broader business environment and a broader perspective on policy challenges requires combining insights from "Doing Business" with data from other sources, such as World Bank Enterprise Surveys. ${ }^{17}$ Other indicators more specific to the regulatory environment for energy investment also need to be studied and assessed. Moreover, political or non-commercial risks are associated with cross border investments and those risks much be managed.

\section{Conclusions}

The battle against climate change requires international cooperation and coordination. Strong incentives exist for individual countries to free ride and the absence of a global government, or a strong international organization to enforce cuts in emissions, make this battle a sharply challenging problem to manage. As discussed in this article, rich countries have preferred to sign bilateral investment treaties with developing and emerging countries rather than having a global investment regime supported by an international organization. This makes long term clean energy investments in developing and emerging markets more problematic. International Financial Institutions (IFIs) tend to serve investors from rich countries rather than the interests of developing host countries. Self-interest and short-sighted (in)action on the part of rich countries make climate change a very difficult problem to manage. Weak institutions and governance problems in developing and emerging countries only add to this problem.

Part of the strategy in the battle against climate change ought to be transition to clean energy sources. This requires infrastructure investment to utilize these sources on a larger scale. This is currently not happening fast enough and investment in developing and emerging markets is often challenging because of underdeveloped business and investment environments. Emerging and developing countries have the largest underutilized clean energy sources in the world and they also have the

${ }^{17}$ See http://www.enterprisesurveys.org 
strongest demand given both current economic and population growth. Clean energy investments like geothermal and hydropower, are large, capital intensive, and long term. Those projects often need sponsorship and funding from public, private and donor sources. This requires international cooperation and coordination, cooperation between the public and the private sector, as well as a fair sharing of risks and rewards.

The success of the World Trade Organization in preserving the long term benefits of an open global trading system is notable. One can argue that the General Agreement on Tariffs and Trade that later became the World Trade Organization is the most successful international organization ever established. In contrast, the current investment regime is mostly bilateral, with decentralized decision making, and no international organization supports the regime: no World Trade Organization is available for cross border investments.

In the absence of a global investment agreement, like the General Agreement on Tariffs and Trade and subsequently the World Trade Organization on trade, investors have turned to piecemeal solutions when protecting their rights in risky countries. This failure to create a global framework for investment is especially serious if one considers capital intensive clean energy projects. The current investment regime seems mainly to be concerned with protecting investors from rich countries against government action in poor countries.

The failure to create a global investment regime traces all the way back to the Bretton Woods conference. In fact, one can hardly talk about any institutionalized cooperation on cross border investments on a global scale. Some regional agreements and interregional agreements address cross border investment but it is unclear yet if those will eventually result in a global arrangement supported by an international organization. Rich countries may be better off with the current arrangement, i.e. the interests of capital exporting countries can continue to dominate developing and emerging countries.

IFIs can be important partners not only with direct funding, i.e. loans and equity investment, but also increasingly through risk mitigation instruments. However, the insurance and guarantee instruments offered by IFIs to promote cross border investments are piecemeal solutions that could nevertheless be useful to leverage funding for clean energy investments. While they have not been used much to support cross border clean energy projects, some signs suggest that e.g. the World Bank may be stepping up its efforts. IFIs can also make important contributions via policy dialogue and technical assistance. Increased investment in clean energy projects can only be part of the solution in the battle against climate change. Nevertheless, it is an important part of the strategy. Investment in infrastructure creates jobs and profits and can thus provide the right incentives for global action. Any global climate agreement needs to construct a finance regime that supports lowcarbon development in developing and emerging countries. The climate finance regime should incentivize decarbonization.

The international community needs to ask two questions: How can we make the global investment regime more effective, especially in promoting clean energy 
investment in developing and emerging markets? How can we reform the IFIs to make them more effective in responding to the climate crisis?

\section{References}

Arezki, R. and Obstfeld, M. (2015). The Price of Oil and the Price of Carbon, available at: http://blog-imfdirect.imf.org/2015/12/02/the-price-of-oil-andthe-price-of-carbon/ (Accessed on 7 December 2017).

Dinh, T. Q. and Hilmarsson H. P. (2012a). What are the Economic Justifications for the Existence of Export Credit Agencies and How Can They Facilitate Cross Border Trade to Emerging Market Economies? Journal of Regional Formation and Development Studies, 2012, 6, p. 15-25, Klaipeda.

Dinh, T. Q. and Hilmarsson, H. P. (2012b). Private Sector Export to Emerging Market Economies During Times of Crisis: How Can Export Credit Agencies Help? Review of International Comparative Management, Volume 13, Issue 1, March 2012, p. 167-180.

Dinh, T. Q. and Hilmarsson. H. P. (2012c). How Can Private Companies Use the Financial Services and Risk Mitigation Instruments Offered by Export Credit Agencies in Emerging Markets? Proceedings. Project Development - Practice and Perspectives. First International Scientific Conference on Project Management in the Baltic Countries. February 8-9, 2012, Riga, University of Latvia, p. 14-25.

Hilmarsson, H. P. (2017). Funding and Risk Mitigation for Cross Border Clean Energy Investment in Developing and Emerging Economies - Some Cases. Review of International Comparative Management, Volume 18, Issue 2, May 2017, p. 183-199.

Hilmarsson, H. P. (2012). Managing Risks in Cross Border Energy Projects in Emerging Markets. Review of International Comparative Management, Volume 13, Issue 5, December 2012, p. 718-732.

International Financial Corporation, IFC. (2014). Handshake: IFC's quarterly journal on public-private partnerships, available at: http://documents.worldbank.org/curated/en/2014/04/19456522/handshakeifcs-quarterly-journal-public-private-partnerships-13 (Accessed on 16 October 2017)

Keohane, R.O. and Victor, D. G. (2011). The Regime Complex from Climate Change. Perspectives on Politics, March 2011, Vol. 9/No. 1, pp $7-23$.

Nordhaus, W. (2013). The Climate Casino - Risk, Uncertainty, and Economics for a Warming World. Yale University Press, New Haven \& London.

Rhodes, F.H.T. (2012). Earth - A Tenant‘s Manual. Cornell University Press, Ithaca and London.

Salacuse, J. W. (2010). The Emerging Global Regime for Investments, Harvard International Law Journal, Volume 51, Number 2, Summer 2010, available at: $\quad$ http://www.harvardilj.org/wp-content/uploads/2010/09/HILJ 512_Salacuse.pdf (Accessed on 2 June 2018) 
Stern Review. (2006). Stern Review: The Economics of Climate Change, available at: http://mudancasclimaticas.cptec.inpe.br/ rmclima/pdfs/ destaques/sternreview report complete.pdf (Accessed on 2 August 2017)

Wells, L. T. (2005). The New International Property Rights. Can the Foreign Investor Rely on Them? In International Political Risk Management. Looking to the Future, Theodore H. Moran and Gerald T. West, Eds. The World Bank Group - Multilateral Investment Guarantee Agency.

World Bank. (2017). Doing Business 2018 - Reforming to Create Jobs, available at: http://www.doingbusiness.org/reports/global-reports/doingbusiness-2018 (Accessed on 2 June 2018)

World Bank. (2015). The World Bank Group A to Z. The International Bank for Reconstruction and Development/The World Bank, Washington, DC 20433.

World Bank. (2012). Green Infrastructure Finance - Framework Report. East Asia and Pacific Region/East Asia Infrastructure Unit (EASIN).

World Bank. (2003). Global Economic Prospects and the Developing Countries in 2003. 